\title{
PENGEMBANGAN PEMBELAJARAN DENGAN MENEKANKAN BUDAYA LOKAL PADA PENDIDIKAN ANAK USIA DINI
}

\author{
Euis Karwati
}

\begin{abstract}
ABSTRAK
Anak usia dini merupakan kelompok anak pada rentang usia 0 sampai 8 tahun, adalah sosok individu yang sedang menjalani suatu proses perkembangan dengan pesat dan sangat mendasar bagi kehidupan selanjutnya. Pada rentang usia ini potensi kecerdasan dan dasar-dasar perilaku seseorang terbentuk. Sedemikian pentingnya masa ini sehingga usia dini sering disebut the golden age. Pada masa ini anak diberi rangsangan pendidikan dengan cara bermain sambil belajar. Permainan yang diterapkan sebaiknya menekankan pada budaya lokal daerah setempat, agar dapat melestarikan dan memupuk rasa cinta terhadap budaya sendiri. Melalui bermain anak beraktivitas dan bersosialisasi dengan lingkungan, mereka mendapatkan pengalaman, pengetahuan dan keterampilan. Sesuai dengan tujuan pendidikan anak usia dini yaitu, "anak mampu mengenal lingkungan alam, lingkungan sosial, peranan masyarakat, dan menghargai keragaman sosial dan budaya serta mampu mengembangkan konsep diri, sikap positif terhadap belajar, control diri dan rasa memiliki".
\end{abstract}

Kata Kunci: anak usia dini, golden age, bersosialisasi, keragaman sosial.

\section{A. Pendahuluan}

Pada hakikatnya belajar harus berlangsung sepanjang hayat. Agar tercipta generasi yang berkualitas, pendidikan harus dilakukan sedini mungkin. Mesikupun sebenarnya pendidikan yang utama dan pertama harus dilakukan di rumah, karena interaksi anak pada mulanya berasal dari rumah. Tetapi seiring dengan perkembangan dan tuntutan jaman banyak muncul dan didirikan lembaga-lembaga pendidikan yang memfasilitasi anak usia dini untuk belajar di luar rumah. Biasanya kebanyakan Pendidikan Anak Usia Dini (PAUD) atau Taman Pengasuhan Anak (TPA) ditujukan bagi anak 3 (tiga) tahun sampai usia 6 (enam) tahun. Tetapi banyak juga yang menyediakan pembelajaran bagi bayi kurang dari 1 (satu) tahun dan seterusnya.

Seiring dengan semakin tinggi kesadaran masyarakat untuk memberikan pendidikan sedini mungkin, para orang tua terutama di daerah perkotaan dan pinggiran kota juga dihadapkan dengan dilema antara tuntutan untuk memenuhi kebutuhan ekonomi yang terus meningkat dan peningkatan persamaan gender sehingga melibatkan kaum ibu (para wanita) untuk bekerja di luar rumah dan berkarir. Sehingga mempercayakan pengasuhan anaknya yang masih usia dini kepada lembaga PAUD atau yang menyelenggarakan Taman Pengasuhan Anak (TPA), ketika kedua orang tuanya sibuk di luar rumah akan lebih aman. Melalui TPA anak mendapatkan perhatian yang lebih cukup dalam hal pembelajaran, layanan kesehatan, gizi dan rangsangan pendidikan bagi perkembangan mental,

Mahasiswa Prodi Pendidikan Dasar SPS UPI 
emosional maupun sosial dibandingkan dititipkan pada pembantu atau orang lain selain orang tua yang tidak memiliki pedoman yang kuat dalam hal pelayanan kebutuhan anak.

Tujuan pendidikan PAUD, sebagaimanahalnya dengan tujuan satuan lembaga pendidikan lainnya, harus selalu mengacu pada tujuan pendidikan nasional.Tujuan pendidikan nasional, sebagaimana yang ditetapkan dalam GBHN adalah mencerdaskan kehidupan bangsa dan mengembangkan manusia Indonesia seutuhnya, yaitu manusia yang beriman dan bertakwa terhadap Tuhan Yang Maha Esa dan berbudi pekerti luhur, memiliki pengetahuan dan nalar, keterampilan, kesehatan jasmani dan rohani, kepribadian yang mantap dan mandiri, serta bertanggung jawab kemasyarakatan dan kebangsaan.

Kondisi PAUD yang berkembang di masyarakat saat ini semakin menjamur, semakin ketat persaingan, semakin beragam program-program yang ditawarkan, terutama lembaga PAUD yang berada di kota besar. Mereka membuat program yang tidak lagi mementingkan kebutuhan anak, tetapi lebih diarahkan untuk memenuhi keinginan dan gengsi orang tua.

Saat ini kepedulian kita terhadap kekayaan dan kearifan budaya lokal bangsa Indonesia sempat diuji. Negara tetangga yang mengklaim beberapa asset budaya bangsa Indonesia menjadi bagian dari akibat tidak adanya penanaman rasa cinta anak-anak didik kita terhadap budaya sendiri. Anak-anak muda sekarang asyik berlatih menyanyi dengan irama rap dan memainkan musik modern. Padahal kita memiliki tarian melayu yang gemulai, tari jawa yang sarat makna, tari banjar yang gemerlap, tarian suku dayak yang menarik, dan lain-lain, bahkan banyak lagu-lagu daerah yang mudah dan indah yang dapat diperkenalkan kepada anak sejak dini.

Secara yuridis UUD 45 pasal 32 menyatakan bahwa "Negara memajukan Kebudayaan Nasional Indonesia di tengah peradaban dunia dengan menjamin kebebasan masyarakat dalam memelihara dan mengembangkan nilai-nilai budanya". Penanaman budaya ini harus dimulai sedini mungkin, dengan cara menanamkan kecintaan secara bertahap dan melatih keterampilan secara berulang dan terus menerus. Selain itu diperkuat dalam tujuan khusus pendidikan anak usia dini yang tercantum di dalam menu generik menyatakan bahwa "Anak mampu mengenal lingkungan alam, lingkungan sosial, peranan masyarakat, dan menghargai keragaman sosial dan budaya serta mampu mengembangkan konsep diri, sikap positif terhadap belajar, kontrol diri, dan rasa memiliki". Maka sudah selayaknya jika kekayaan alam dan kearifan budaya lokal, menjadi salah satu bagian dari kegiatan pembelajaran yang dapat dilakukan oleh pengelola dan para pendidik/pengasuh Taman Pengasuhan Anak.

Menghadapi era globalisasi diperlukan anak-anak yang unggul untuk menjadi generasi penerus bangsa dimasa depan. Mengingat hal tersebut, dipandang perlu untuk mengembangkan suatu layanan PAUD yang dapat membentuk dan melahirkan anak-anak unggul. Makalah ini merupakan kajian dari berbagai artikel tentang Pengembangan Pembelajaran yang Menekankan Budaya Lokal pada Pendidikan Anak Usia Dini. 


\section{B. Pembahasan}

\section{Pengertian Pembelajaran}

Proses pembelajaran merupakan proses tahap demi tahap yang terperinci, tergambar dan sekuensi logis dari informasi yang akan di sajikan (Hera Lestari dkk, 2002). Proses pembelajaran berpegang teguh pada prinsip dan pemahaman aliran behaviorisme yang menekankan pada pentingnya keterampilan dan pengetahuan akademik maupun perilaku sosial sebagai hasil belajar. Pendekatan yang digunakan pada proses belajar adalah pendekatan akademik, pendekatan ini lebih menekankan pada penguasaan secara tuntas (mastery) terhadap apa-apa yang dipelajari.

\section{Pembelajaran pada Pendidikan Anak Usia Dini}

Pendekatan Montessori dalam Santrock (2012) adalah model filosofi pendidikan dari Maria Monterssori (1870-1952), merupakan filosofi pendidikan dimana anak-anak diberi kebebasan dan spontanitas dalam memilih berbagai aktivitas. Mereka diizinkan untuk beralih dari suatu aktivitas ke aktivitas lainnya sesuai dengan keinginan mereka. Guru lebih bertindak sebagai seorang fasilitator daripada sebagai seorang pemimpin. Kepada anak-anak tersebut, guru memperlihatkan cara menampilkan aktivitas intelektual, mendemonstrasikan caracara mengeksplorasi materi-materi kurikulum, dan menawarkan bantuan kepada anak ketika mereka memintanya. "Dengan mendorong anak untuk membuat keputusan sejak usia dini, program-program Montessori berusaha mengembangkan anak-anak yang dapat meregulasi-dirinya dan memecahkan masalahnya, serta mampu membuat keputusan dan mengelola waktu secara efektif".

Tujuan program pembelajaran adalah membantu meletakkan dasar kearah perkembangan sikap pengetahuan, keterampilan dan kreativitas yang diperlukan oleh anak untuk dapat menyesuaikan diri dengan lingkungannya dan untuk pertumbuhan serta perkembangan pada tahap berikutnya. Untuk mencapai tujuan program pembelajaran tersebut, maka diperlukan strategi pembelajaran bagi anak usia dini yang berorientasi pada:

a. Tujuan yang mengarah pada tugas-tugas perkembangan disetiap rentang usia anak;

b. Materi yang diberikan harus mengacu dan sesuai dengan karekteristik dan kebutuhan yang sesuai dengan taraf perkembangan anak (DAP=Developmentally Approriate Praciticce)

c. Metode yang dipilih seharusnya bervariasi sesuai dengan tujuan kegiatan belajar dan mampu melibatkan anak secara aktif dan kreatif serta menyenangkan

d. Media dan lingkungan bermain yang digunakan haruslah aman, nyaman dan menimbulkan ketertarikan bagi anak dan perlu adanya waktu yang cukup untuk bereksplorasi

e. Evaluasi yang terbaik dan dianjurkan untuk dilakukan adalah rangkaian sebuah assesment melalui observasi parsitipan terhadap segala sesuatu yang dilihat, didengar dan diperbuat oleh anak. 


\section{Media Pembelajaran pada Anak Usia Dini}

Kata media sendiri berasal dari bahasa latin dan merupakan bentuk jamak dari kata medium yang secara harfiah berarti "perantara". Dengan demikian maka media merupakan wahana penyalur informasi belajar atau penyalur pesan. Secara khusus pengertian media dalam proses belajar mengajar cenderung diartikan sebagai alat-alat grafis, fotografis atau elektronis untuk menangkap, memproses dan menyusun kembali informasi visual dan verbal (Rostina, 2013:4)

Apabila kata media pendidikan digunakan secara bergantian dengan istilah alat bantu atau media komunikasi seperti yang dikemukakan oleh Hamalik (1989) bahwa hubungan komunikasi akan berjalan lancer dengan hasilyang maksimal apabilamenggunakan alat bantu yang disebut media komunikasi.

Gagne dan Briggs (1975) dalam Arsyad (2002) secara implisit menyatakan bagwa media pembelajaran meliputi alat yang secara fisik digunakan untuk menyampaikan isi materi pengajaran, dengan kata lain media adalah komponen sumber belajar atau wahana fisik yang mengandung materi instruksional di lingkungan siswa yang dapat merangsang siswa untuk belajar.

\section{Pembelajaran berbasis budaya lokal}

Teori Vygotsky dalam Santrock (2011:274) menyajikan pendekatan konstruktivis sosial terhadap perkembangan. Menurut Vygotsky anak-anak menyusun pengetahuannya melalui interaksi sosial, dan mereka menggunakan bahasa tidak hanya untuk berkomunikasi dengan yang lain, namun juga untuk merencanakan, mengarahkan dan memonitor tingkah lakunya sendiri serta untuk membantu mereka memecahkan masalah-masalahnya sendiri. Konsep teori ini adalah ZPD atau zona perkembangan proksimal adalah istilah Vygotsky untuk menyatakan bahwa orang dewasa bisa membimbing dan memberikan bantuan untuk menghadapi hal-hal yang dianggap sulit oleh anak. Konsep ZPD erat kaitannya dengan Scaffolding, yaitu menghadirkan orang yang lebih terampil secara bertahap mengubah level dukungan di dalam rangkaian sesi pengajaran disesuaikan dengan level performa siswa.

Sebagaimana yang dikatakan Vigotsky bahwa kontribusi budaya, interaksi sosial dan sejarah dalam pengembangan mental/perilaku anak sangat berpengaruh. Pembelajaran yang berbasis pada budaya dan interaksi sosial mengacu pada aspek perkembangan sosio-historis-kultural, akan sangat berdampak pada persepsi, memori dan cara berpikir anak.

\section{Pembelajaran Berbasis Budaya Lokal pada Anak Usia Dini}

Pendidikan usia dini merupakan upaya-upaya pendidikan yang dilakukan dengan sadar untuk mengembangkan berbagai potensi yang dimiliki anak. Potensipotensi tersebut meliputi aspek fisik, kognitif, bahasa, motorik, moral, disiplin, sosial-emosional, konsep diri, seni, dan nilai-nilai agama. Pembelajaran merupakan suatu kegiatan melaksanakan kurikulum suatu lembaga pendidikan agar dapat mempengaruhi para siswa mencapai tujuan pendidikan yang telah ditetapkan. Tujuan pendidikan pada dasarnya mengantarkan para siswa menuju pada 
perubahan-perubahan tingkah laku baik intelektual, moral, maupun sosial anak agar dapat hidup mandiri sebagai individu dan mahluk sosial.

Dalam mencapai tujuan tersebut siswa berinteraksi dengan lingkungan belajar yang diatur guru melalui proses pembelajaran. Lingkungan belajar yang diatur oleh guru mencakup tujuan pembelajaran, bahan pembelajaran, metodologi pembelajaran, dan penilaian pembelajaran. Secara khusus terkait metodologi pembelajaran, aspek ini terkait dengan dua hal yang saling menonjol yaitu metode dan media pembelajaran. Media memiliki kedudukan yang sangat penting dalam mencapai tujuan pembelajaran secara efektif.

Bermain merupakan suatu kegiatan yang menyenangkan bagi anak dan juga merupakan salah satu cara belajar bagi anak usia dini, karena melalui bermain anak memperoleh kesempatan untuk bereksplorasi, menemukan, mengekspresikan perasaannya dan berkreasi. Selain itu, kegiatan bermain berkaitan erat dengan perkembangan kognitif anak.

Belajar melalui bermain intinya melakukan kegiatan belajar melalui permainan yang bersifat mendidik dan terarah. Dalam belajar melalui bermain, anak dibawa kepada suatu kondisi permainan yang sangat bervariasi untuk membuat anak benar-benar menjiwai permainan tersebut dalam suasana yang menyenangkan sesuai dengan perannya masing-masing. Hingga tanpa mereka sadari, mereka belajar banyak melalui permainan-permainan tersebut. Pada dasar-nya setiap kegiatan bermain membawa dampak positif terhadap perkembangan anak. Selain keterampilan, aspek perkembangan keimanan dan ketakwaan, daya fikir, daya cipta, kemampuan berbahasa, kemandirian dan kemampuan jasmani.

Cara belajar anak melalui bermain ini, didasari oleh pendapat para ahli tentang ciri-ciri anak usia dini secara umum yaitu: anak penuh dengan rasa ingin tahu, senang membentuk dan memanipulasi benda-benda, senang meniru orang dewasa, memerlukan partisipasi dalam kegiatan fisik, ingin mengekspresikan diri secara kreatif, dan ingin berkomunikasi dan berbagi pengalaman.

Selain sebagai media untuk eksplorasi dan belajar, bermain juga membantu anak mengenal dirinya, mengenal dengan siapa ia hidup serta mengenal lingkungan tempat di mana ia hidup. Karena itu, lingkungan bermain anak, baik fisik maupun psikologis (nilai-nilai dan norma), sangat mempengaruhi proses pembelajaran yang akan diterima oleh anak. Demikian pula lingkungan budaya, khususnya budaya lokal dimana anak tinggal juga akan sangat berperan dalam membentuk karakter anak dalam menerima pembelajaran tentang diri dan dunianya.

Media dalam proses pembelajaran dapat mempertinggi proses belajar siswa dalam pembelajaran yang pada gilirannya diharapkan dapat mempertinggi hasil belajar yang dicapainya. Berbagai penelitian yang dilakukan terhadap penggunaan media dalam pembelajaran sampai pada kesimpulan, bahwa proses dan hasil belajar pada siswa menunjukkan perbedaan yang signifikan antara pembelajaran tanpa media dengan pembelajaran menggunakan media. Oleh karena itu penggunaan media pembelajaran sangat dianjurkan untuk mempertinggi kualitas pembelajaran.

Peran media dalam pembelajaran khususnya dalam pendidikan anak usia dini semakin penting artinya mengingat perkembangan anak pada saat itu berada pada masa berfikir konkrit. Oleh karena itu salah satu prinsip pendidikan untuk anak usia 
dini harus berdasarkan realita artinya bahwa anak diharapkan dapat mempelajari sesuatu secara nyata. Dengan demikian dalam pendidikan untuk anak usia dini harus menggunakan sesuatu yang memungkinkan anak dapat belajar secara konkrit. Prinsip tersebut mengisyaratkan perlunya digunakan media sebagai saluran penyampai pesan-pesan pendidikan untuk anak usia dini. Seorang guru pada saat menyajikan informasi kepada anak usia dini harus menggunakan media agar informasi tersebut dapat diterima atau diserap anak dengan baik dan pada akhirnya diharapkan terjadi perubahan-perubahan perilaku berupa kemampuan-kemampuan dalam hal pengetahuan, sikap, dan keterampilannya.

Atas dasar hal tersebut di atas, maka kurikulum model pembelajaran Berbasis Budaya Lokal ini dikembangkan berdasarkan karakteristik anak, yakni bermain kreatif dan juga mengejawantahkan nilai-nilai budaya lokal dalam program pembelajaran anak usia dini dalam rangka mengembangkan seluruh potensi anak.

Anak usia dini adalah individu yang berbeda, unik, dan memiliki karakteristik tersendiri sesuai dengan tahapan usianya. Oleh karenanya upayaupaya pengembangan pendidikan yang dilakukan hendaknya disesuaikan dengan karakteristik masa kanak-kanak tersebut, yaitu bermain.

Dalam pelaksanaan pembelajarannya kearifan budaya lokal pada anak usia dini disajikan dalam bentuk tema-tema. Tema ini berfungsi untuk menyatukan isi kurikulum dalam dalam satu perencanaan yang utuh (holistik), memperkaya perbendaharaan bahasa anak didik, membuat pembelajaran lebih bermakna dan membantu anak mengenal berbagai konsep secara mudah dan jelas. Jadi tema merupakan aktualisasi konsep minat anak yang dijadikan fokus perencanaan atau titik awal perencanaan dalam proses pembelajaran. Untuk menyiapkan pembelajaran berbasis kearifan budaya lokal maka tema yang dipilih untuk dikembangkan di PAUD disesuaikan dengan kondisi daerah masing-masing. Pemilihan tema di PAUD hendaknya memperhatikan prinsip-prinsip sebagai berikut:

1. Kedekatan: tema hendaknya dipilih dimulai dari tema yang terdekat dengan kehidupan anak kepada tema yang semakin jauh dari kehidupan anak.

2. Kesederhanaan: tema hendaknya dipilih mulai dari tema-tema yang sederhana kepada tema-tema yang lebih rumit bagi anak.

3. Kemenarikan: tema hendaknya dipilih mulai dari tema-tema yang menarik minat anak kepada tema-tema yang kurang menarik minat anak.

4. Keinsidentalan: peristiwa atau kejadian di sekitar anak (sekolah) yang terjadi pada saat pembelajaran berlangsung hendaknya dimasukkan dalam pembelajaran walaupun tidak sesuai dengan tema yang dipilih pada hari itu.

Oleh karena itu disusun Kurikulum Model Pembelajaran Melalui Bermain Kreatif Berbasis Budaya Lokal disusun sebagai panduan program pembelajaran bagi anak usia 3-6 tahun. Bermain Kreatif adalah segala bentuk permainan yang dapat merangsang segala aspek tumbuh kembang anak, baik fisik-motorik, kognitif, sosialemosional, bahasa dan juga kreatifitas. Kegiatan bermain kreatif yang diterapkan dalam kurikulum Model Pembelajaran.

Dalam penerapannya pembelajaran melalui bermain dengan berbasis budaya lokal khususya kita di wilayah jawa barat diantaranya adalah:

a). Bermain oray-orayan, paciwit-ciwit lutung 
b). Sabintrong, sondah, boy-boyan

c). Rerebonan

d). Bernyanyi sambil menari, misalkan dengan nyanyian Tokecang, trangtrang kolentrang, dll.

e). Sandiwara Lutung kasarung dan Sangkuriang

f). Tokoh-tokoh dalam Wayang Golek (Arjuna, Cepot, Semar, Dawala, dll.)

Adapula Permaian edukatif dengan dikembangkannya Pembuatan APE (Alat Permainan Edukatif). Permainan edukatif merupakan suatu kegiatan yang sangat menyenangkan dan dapat merupakan cara atau alat pendidikan yang bersifat mendidik dan bermanfaat untuk meningkatkan kemampuan berbahasa, berpikir serta bergaul dengan lingkungan atau untuk menguatkan dan menterampilkan anggota badan si anak, mengembangkan kepribadian, mendekatkan hubungan antara pendidik dengan peserta didik, kemudian menyalurkan kegiatan anak didik dan sebagainya.

Permainan edukatif juga dapat berarti sebuah bentuk kegiatan yang dilakukan untuk memperoleh kesenangan dari cara atau media pendidikan yang digunakan dalam kegiatan bermain, yang disadari atau tidak, memiliki muatan pendidikan yang dapat bermanfaat dalam mengembangkan diri peserta didik.Artinya, permainan edukatif merupakan sebuah bentuk kegiatan mendidik yang dilakukan dengan menggunakan cara atau media permainan yang bersifat mendidik. Ringkasnya, permainan edukatif adalah permainan yang bersifat mendidik.

Contoh APE untuk anak usia dini diantaranya: Boneka Jari, Puzzle, Kotak Alfabet, Kartu Lambang Bilangan, Kartu pasangan, Puzzle Jam, Lotto Warna, Botol Aroma, Bola Suara dan lain-lain.

\section{KESIMPULAN}

Dunia anak adalah dunia bermain, melalui bermain anak memperoleh pelajaran yang mengandung aspek perkembangan kognitif, sosial, emosi dan perkembangan fisik. Melalui kegiatan bermain dengan berbagai permainan anak dirangsang untuk berkembang secara umum baik perkembangan berpikir, emosi maupun sosial.

Pendidikan anak usia dini (0 sampai 8 tahun) merupakan tempat belajar sekaligus bermain bagi anak-anak. Mereka diajarkan mengenal aturan, disiplin, tanggung jawab dan kemandirian dengan cara bermain. Anak juga diajarkan bagaimana mereka harus menyesuaikan diri dengan lingkungannya, berempati dengan temannya, tentunya juga berlatih bekerja sama dengan anak yang lain. Melalui kegiatan bermain yang mengandung edukasi, daya pikir anak terangsang untuk merangsang perkembangan emosi, perkembangan sosial dan perkembangan fisik. Setiap anak memiliki kemampuan dan ketertarikan bermain yang berbeda tergantung dari perkembangan anak. Dari permainan juga biasanya akan menimbulkan fantasi-fantasi besar oleh anak, dan tentu akan semakin menambah rasa ketertarikan anak pada mainan tersebut.

Di dalam menyiapkan media dan materi pembelajaran perlu dikaitkan dengan keseharian atau budaya yang sesuai dengan lingkungan dimana anak berinteraksi. Sehingga memang usaha keras dan juga kreativitas dari guru sangatlah 
dituntut. Tanpa kesediaan guru untuk mencari sumber informasi yang banyak dan juga kreativitas dalam mempersiapkan materi dan media pembelajaran tentulah kegiatan dalam pendidikan media menjadi tidak bermakna. Guru harus dapat menurunkan dalam tingkat yang kongkrit sesuai dengan tahap perkembangan anak pada masa usia dini yaitu praoperasional apa yang dimaksud dalam pendidikan media tersebut, mencari contoh-contoh yang melingkupinya, memilih topik-topik apa saja yang bisa dan bermakna bagi anak di tingkat usia dini. Dengan memperhatikan hal-hal tersebut dapat diasumsikan guru telah bisa memberikan fondasi munculnya anak melek media. Dasar menjadi melek media di tingkat usia dini ini harus terus dipupuk di tingkat pendidikan lanjutannya agar menjadi utuh terbangun pada diri anak yang kelak ketika dia dewasa telah dapat menggunakannya dengan baik.

Alat permaian edukatif (APE) merupakan bagian yang tidak terpisahkan dalam pembelajaran anak di Taman Kanak-kanak atau Pendidikan anak usia dini (PAUD). Kesediaan alat permainan tersebut sangat menunjang terselenggaranya pembelajaran anak secara efektif dan menyenangkan sehingga anak-anak dapat mengembangkan berbagai potensi yang dimilikinya secara optimal.

Permainan edukatif yang mendukung pembelajaran berbasis budaya lokal, diperlukan untuk dapat memenuhi kebutuhan anak dalam rangka belajar melalui bermainnya sambil memperkenalkan dan menanamkan nilai-nilai budaya dan rasa cinta pada produk budaya lokal. Tak banyak anak di kota besar yang kenal dengan rumah adat, alat transportasi tradisional, tanaman, tumbuhan dan hewan, serta kerajinan khas daerah. Oleh karena itu, diperlukan mengembangkan media permainan edukatif yang berbasis budaya lokal.

Penyusunan model pengembangan alat permainan edukatif ini dapat membantu guru PAUD dalam rangka menyediakan APE berbasis lokal, untuk mengembangkan dan menstimulasi seluruh aspek kecerdasan yang masing-masing dimiliki oleh anak. Selain itu dengan APE berbasis lokal dapat mengenalkan budaya dan keunggulan didaerahnya. Guru mengenalkan kepada anak usia dini secara bertahap dan berulang-ulang dapat menanamkan kecintaan anak terhadap budaya daerah sebagai akar budaya bangsa. Alat permainan edukatif berbasis lokal diharapkan dapat menunjang kreativitas anak untuk mempersiapkan kemandirian, kematangan dan keterampilan menyongsong pembelajaran ke jenjang selanjutnya.

\section{DAFTAR PUSTAKA}

Arsyad, Azhar.( 2002). Media Pembelajaran. Jakarta: PT Raja Grafindo Persada.

Effendi, R. \& Setiadi, Elly M. (2006). Pendidikan dan lingkungan sosial budaya dan teknologi.

Hamalik, Oemar. (1989). Media Pendidikan. Bandung: PT Citra Aditya Bakti.

Lestari M., Hera. (2002). Modul UT Pendidikana Anak Usia SD. Jakarta: Universitas Terbuka.

Santrock, J. W. (2012) Life-Span Development. Jakarta. Erlangga

Sujiono, Y. N. (2009). Konsep Dasar Anak Usia Dini. Jakarta. Indeks.

Sundayana, Rostina. (2013). Media Pembelajaran. Bandung: Alfabeta

Tim Redaksi Fokusmedia. (2004). UUD'45 dan Amandemennya. Bandung Fokusmedia 